\title{
AMITOSIS IN THE EMBRYO OF FASCIOLARIA.
}

HENRY LESLIE USBORN.

A Number of years ago, while studying the embryology of Fasciolaria, I noticed evidences of amitosis in three different locations. As biological opinion has not reached a state of rest in regard to amitosis and its relation to mitosis, I have felt that a study of the facts in this case would perhaps prove of interest. A few brief references to the literature of the subject will show the unsettled condition of public opinion in this matter. Waldeyer ('90) said that "nuclear division is a single process with Remak's simple amitotic clivision as the funclamental form." Johnson ('92), on the contrary, said that he was " convinced that it (amitosis) is not derived from mitosis, and on the other hand is not a forerunner of the more complicated process." Johnson considers it a different type which along with karyokinesis has been transmitted from the simplest forms of life to the most highly organized. Nor is there unanimous consent as to the significance of amitosis. The bulk of observation is to the effect that mitosis is found in growing (i.c., regenerative) tissue and amitosis is found in senescent, metabolic or pathologic tissue. In I 89 I Ziegler contended that amitosis is due to senescence of highly active secretory action in cells, and vom. Rath ('94) espoused this view and clefended it strongly. According to these writers amitosis is never regenerative (i.c., found in developing tissue), but seals the fate of a nucleus which can never subsequently divide mitotically. E. B. Wilson in his work, The Coll, appears to be less favorably disposed to accept this view in the 1900 edition of his work than in the edition of 1896 ; in the I 900 edition he says that the view is "too extreme," though "there can be no cloubt but that Flemming's hypothesis in a general way represents the truth, and that in the vast majority of cases amitosis is a secondlary process which does not fail in the generative series of cell-divisions." 
Some observations exceptional to this law may be briefly cited. Frenzel ('85) found in the intestine of certain decapods that the epithelium is regenerated from basal cells which show all stages of amitosis, while in other closely related genera the growth is from mitotic nuclei. Wheeler ('89) found that in the early blastoderm of Blatta all the nuclei divide amitotically at a certain stage, and that this is followed later by mitosis. Goppert ('9r) found amitosis in the leucocytes of the salamander's liver which he regards as regenerative. Verson ('9I) found that in the testis of the silkworm single large nuclei divide amitotically while their daughter cells give rise to spermatocytes mitotically. Meves ('9r) found that in the salamander certain of the cells of the testis divided amitotically in winter and mitotically in summer. Preusse ('95) found mitosis in the youngest egg compartments of the ovaries of hemiptera, which consist of only a few cells and where active cell multiplication must be taking place. This writer cites observations of Carnoy and Claus in support of his claim that amitosis is regenerative in some cases. Pfeffer ('99, Wilson, : oo) found that if "spirogyra be placed in water containing $0.5-\mathrm{r} .00 \%$ of ether active growth and division continue, but only by amitosis. If, however, the same individuals be replaced in water mitotic division is resumed and an entirely normal growth continues."

These various observations upon amitosis all indicate a close relation between amitosis and mitosis. The fact that nuclei divide in one way in winter and in the other in summer, that in one genus one method prevails and in another related genus the other, and that mitosis can be replaced in the same cell by amitosis under the influence of ether, all of them suggest a process at bottom the same but operating differently under the influence of different circumstances. If so, we should regard amitosis as the more primitive mode and mitosis as a more highly specialized mode derived from it. And we need not then be surprised if the more primitive mode should occasionally occur in a place where on general principles we should look for the more highly specialized one. Though we generally find cell multiplication to be associated with mitosis and special metabolic activity to be associated with amitosis, we might in special cases find that cells 
were multiplying by amitosis, the simpler mode having been adopted for local reasons.

The material on which this paper is based was collected at Beaufort, North Carolina (Osborn, '85), and preserved in either cold aqueous corrosive sublimate, picronitric or chromic acid solution. Sections were cut serially and stained on the slide in borax-carmine, in the clays before iron-hrematoxylin had been

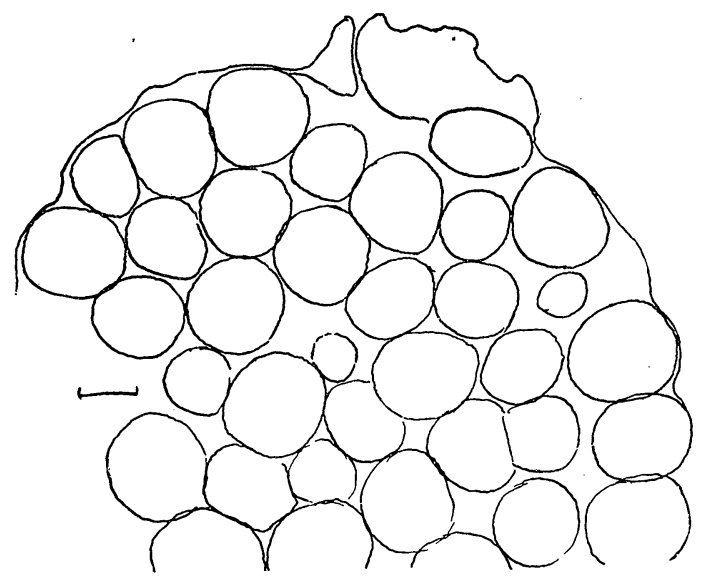

FIG. $_{\text {IG. }}$ - Section of embryo in plane of the throat, showing the very thin ectoderm, partial endoderm and food-ova. Scale $0.1 \mathrm{~mm}$., cam, luc. $\times 60$.

discovered. I should have been glad to check these results by more recent methods had access to fresh material been possible; however, the technique is fairly adequate for my purpose, as shown by the condition of the mitotic nuclei present and many other delicate cytological details. A brief account of the structure of the embryo will facilitate orientation, especially as this form is consiclerably aberrant. My studies at Beaufort were broken off before I had gotten the earliest stages. Sections of my earliest embryo are shown in Figs. I and 2. It is already past the gastrula stage, and consists of an extremely attenuated ectoderm enclosing a great number of small spherules each of approximately O.I $5 \mathrm{~mm}$. in cliameter. There is a throat and a small amount of ectoderm, not nearly enough to enclose the spherules. The spherules are made up of a small mass of cyto- 
plasm and a great many yolk granules enclosed by a sharp cell wall. In the centre of the cytoplasm there is a nucleus or more than one. These structures are not the ordinary yolk cells resulting from segmentation of the endodermal part of the original ovum, but according to MacMurrich ('87) they are unfertilized ova which were discharged into the egg capsule by the mother at the time of its formation together with the true eggs. He says " each egg capsule contains a large number, perhaps two hundred, of ova measuring about $0.25 \mathrm{~mm}$. across; of these

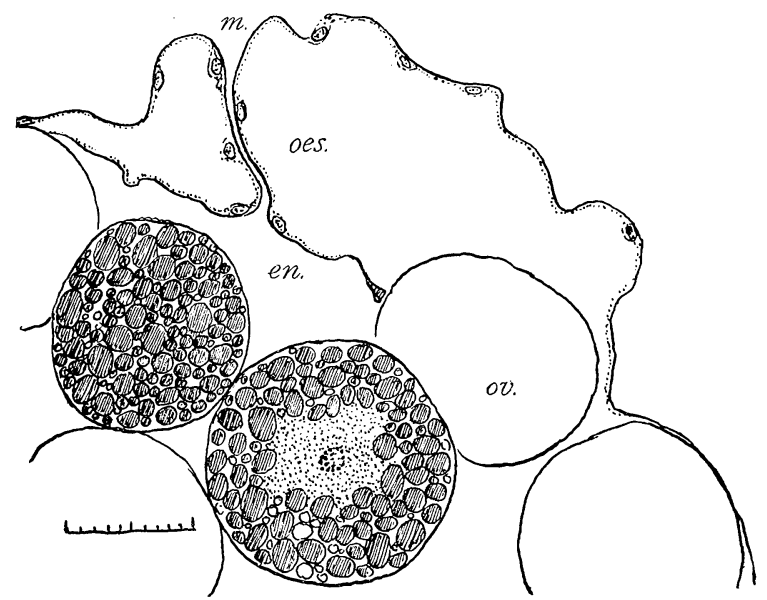

FIG. 2. - More highly magnified view of part of figure 1 , scale 0.1 mm., cam. luc. $\times \cdot 30$.

only four or six ever develop, the rest being swallowed by the developing embryos and used as food. The non-developing ova do not ever segment nor push out polar globules, nor do they break down or disintegrate, but are ingested by the embryos so that at an early stage one of these appears to consist of a large number of ova bound together into a ball." The embryo of Fasciclaria is thus very unlike that of related prosobranchs such as Nassa, in which the yolk is a part of the original structure of the egg cell, and hence part of the endoderm of the embryo, while in Fasciolaria the egg segments and reaches the gastrula stage and then swallows the other eggs itself having no supply of food. The ova thus swallowed I shall call food ova.

The larval kidneys are conspicuous organs in many proso- 
branch embryos, but they do not reach such large dimensions or become such conspicuous objects in any other described forms as in Fasciolaria. They are called "sub-velar masses" in my paper of ' 85 , and are shown in Figs. I, 2, 3, 4, and 5. They are very early of development and are already conspicuous organs when the shell gland first shows. The velum subsequently arises and spreads out over them. In the earliest embryos the ectoderm cells of the area on each side of the mouth undergoes a peculiar change (Fig. 3), the boundaries of the cells cannot be seen, vacuoles of various sizes appear in the cytoplasm, and some of the larger vacuoles push the nuclei aside compressing the nucleus, much as in the fat cells of vertebrates. This is the first step in the development of the larval kidney. The nuclei at this time still show mitosis, two of the cells of the figure are in stages of active karyokinesis, there is no evidence as yet of amitosis. As the accumulation of material within the cell goes on, the outer end is pushed up above the general level of the ectoderm and becomes the swollen organ we see. The cells become wedge-shaped, each retains its place on the ectoderm by its base, the

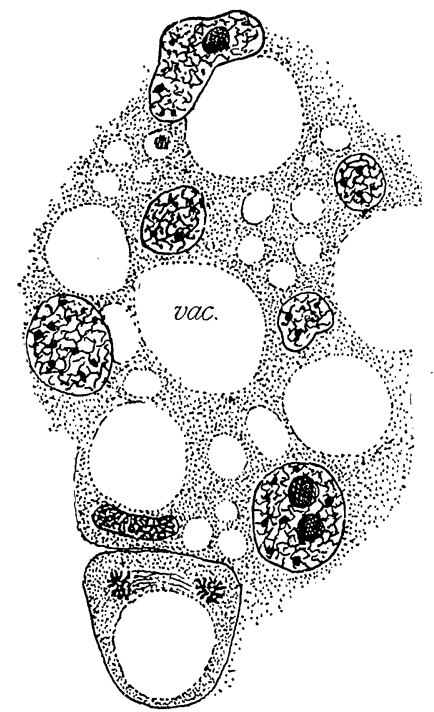

FIr. 3.- Surface view (tangential section) of ectoderm at one side of the mouth, showing first stages in the formation of the larval iidney.

cytoplasm is pushed out into the outer end of the cell, which becomes rounded there as if through the influence of pressure from within. The content of the cell is chiefly a material which in life is fluid and highly refractive, but it is coagulated by preservative reagents; it is faintly stainable and not dissolved by absolute alcohol or oil. The cytoplasm at the outer end of the cell (Fig. 4) contains one or more nuclei. The relation of the cells to the general ectoderm is shown in Fig. 4 ; the organ is considerably constricted at its base.

There are no evidences of cell division among the older cells; 
additions are evidently made at the periphery of the organ at the expense of the ordinary ectoderm cells. But though the older cells are not dividing, there are many of them in which the cytoplasm at the outer end contains two nuclei, so that we infer that nuclear division has been going on. No mitotic figures are to be found in these cells but there are evidences of amitosis. Fig.

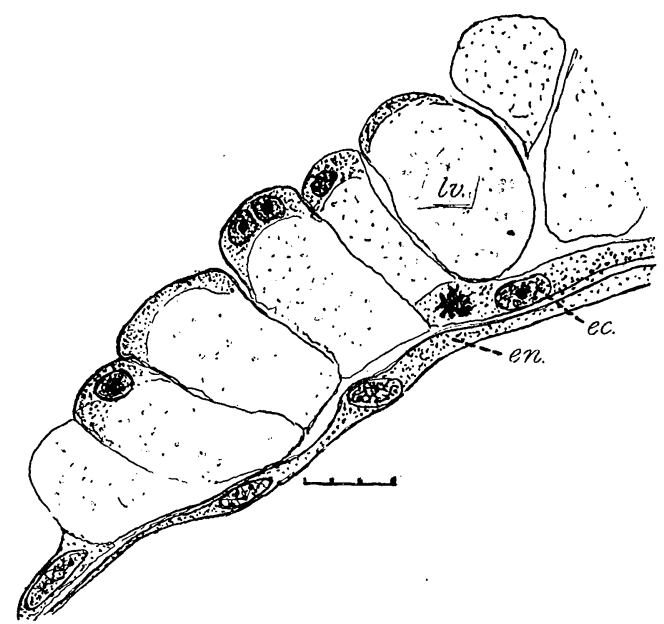

FIG. 4.- Section of the larval kidney at a later stage than figure 3, showing the ectodermal cells greatly enlarged by the secreted material, and the cytoplasm occupying the outer end of the cell, cam. luc. $\times 2$ ir. Scale $=$. or $\mathrm{mm}$.

5 shows three stages of this: in the lower figure the initial constriction, in the middle one the completion of the division, and in the upper one the two nuclei have moved apart.

The physiological significance of this organ is inclicated by its name. As usual with prosobranchs, the embryo develops inside an impervious capsule; consequently it is of great importance that the wastes from its actively developing tissues be kept out of contact with them. This is done by intracellular storage. The barrier of living cytoplasm at the outer end of the cell keeps the cell the better from disintegrating there and the contained material from escaping. This device reminds one of the lepidoptera and their scales as reservoirs for waste nitrogen during metamorphosis.

Amitosis here is clearly in accordance with the view that senescence and amitosis are closely related, for these cells are 
plainly reaching the end of their career. Though they are for the time a part of a very young embryo, the organ is no more an integral part of the embryo than are the embryonic membranes of arachnids and insects, in which amitosis is well known to be associated with senescence. It is really merely an embryonic structure. It is not, however, clear that the active secretory function of these cells is a cause of the amitosis. If it were we should expect that in

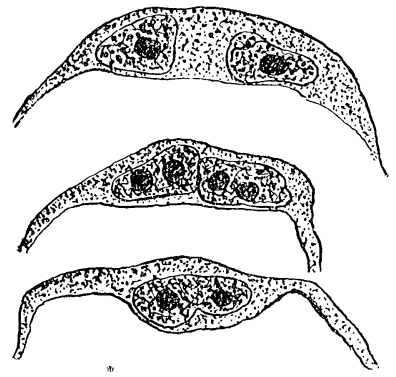

Fici. 5. - Outer ends of three cells from same situation as figure 4 , showing nuclei in different stages of division, cam. luc. $\because$ 6oo.

cells where it was taking place as actively as in the one in Fig. 3 at the bottom of the drawing should show amitosis, whereas it and the one over it are dividing amitotically.

The food-ova present nuclear appearances of sufficient interest to deserve mention. In the earliest embryos (Figs. I, 2) they are intact and still manifest cell activities of their own notwith-

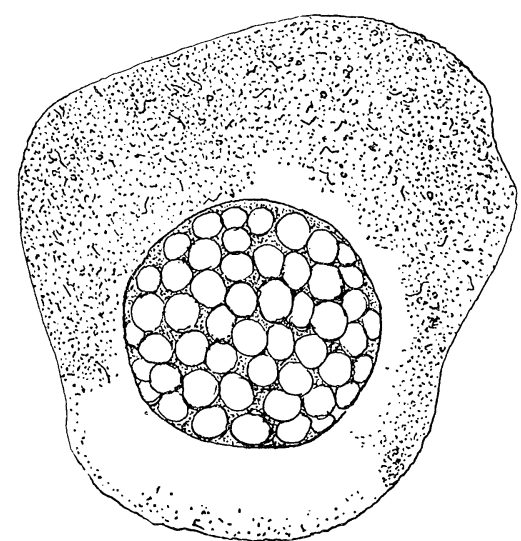

FIcr. 6. - The nucleus and immediately adjacent cytoplasm of one of the food-ova, vacuolated condition of the nucleus, cam. luc. $\times 600$. standing their having been swallowed as food. Each has a definite egg-membrane enclosing a mass of cytoplasm often located near the surface of the cell, its branches reaching out among the very numerous grains of yolk. Many of these ova exhibit peculiar nuclear activities. In some one finds a single nucleus near the centre of the cytoplasm of large size and containing within its membrane not the more customary chromatine network but instead a mass of bubbly material (fig. 6) as if the chromatine had been converted into a froth. Other cases are met in which there are numerous small nuclei, as in Fig. 8. 
In such cases the centre of the protoplasmic area often contains a somewhat more deeply stained material not limited by any distinct boundary from the general cytoplasm, but occupying the position of the single nucleus of other ova and having the same size, and the cytoplasm often radiates from this as a centre of influence. The lesser nuclei do not usually show active division, but are in the resting stage. They show evidences of disorganization in various respects. Some are distinctly vacuolated as the parent nucleus was; others contain bits of chromatine of no regular shape or position, resembling very closely the "spore-like bodies" found by Herrick ('92) in the "degenerating nuclei" of the yolk cells of the egg nauplius of Alpheus. In a few instances two of these smaller nuclei are still connected by a thread of stainable material, as in Fig. 7, which I interpret as the last stage in amitotic division, and an indication of the proc-

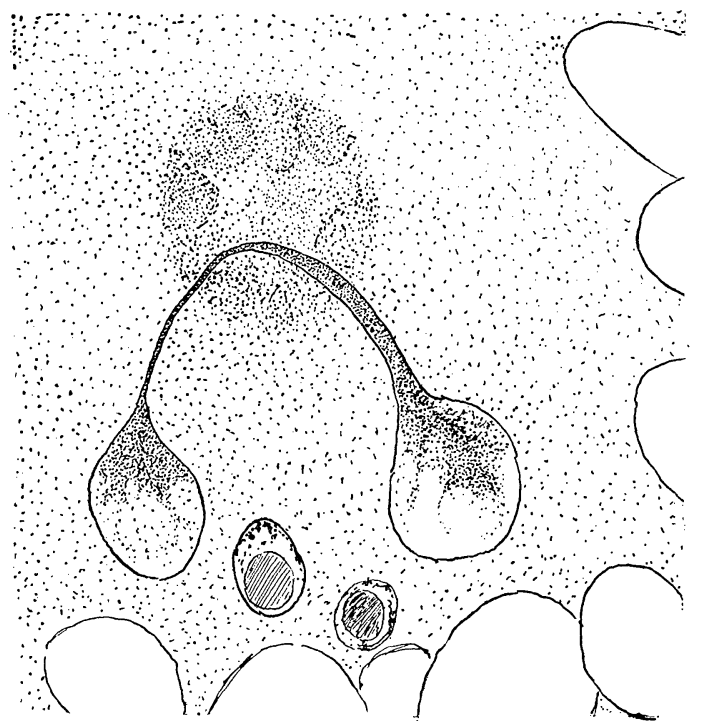

FIG. 7.- Nuclei and surrounding cytoplasm, showing the last stage in a nuclear division, cam. luc. $\times 600$.

ess by which the multiple nuclei of the food-ova have been formed. The cells in which the nuclei have undergone these changes are on the road to complete breakdown and these changes are the last events in their lives. The process is a 
futile attempt at segmentation where normally we should find mitosis, but in this case the cell having the impulse to divide but being powerless to do so by mitosis falls back on the easier mode and does so by amitosis. We may call it cell senescence.

The gastrulas before they have swallowed the food-ova are (according to information and drawings access to which I owe to the kindness of Prof. MacMurrich) very queer looking objects on account of the very ample folds of the ectoderm to allow for the distension which is to follow. One would expect that the endoderm would be equally so, in order to receive the ova into an endoderm-lined cavity, but after much study of this point I am convinced that unusual as it is there is not enough endoderm to enclose these ova, but only a very small amount reaching out a short distance from the throat in all directions, as in Fig. 2.

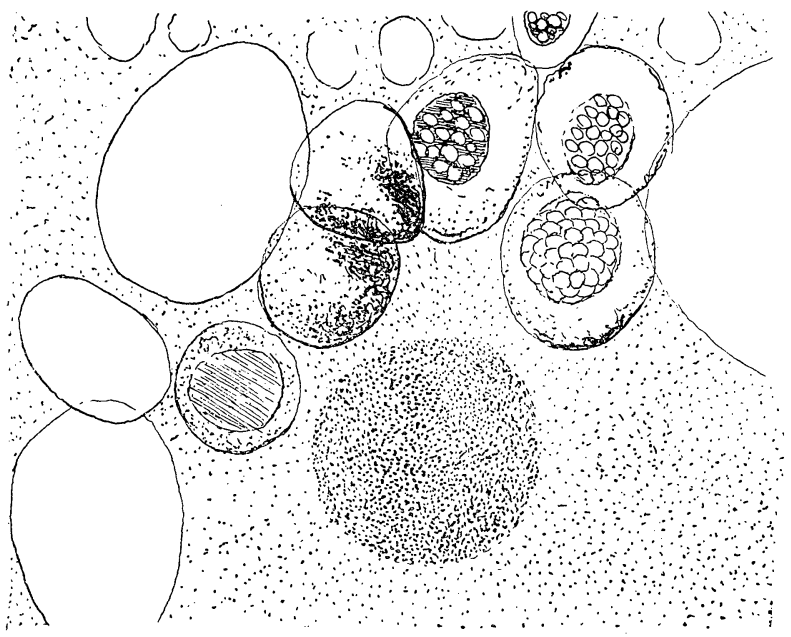

FIG. S.- Multi-nucleate condition of older food-ovum, the nuclei showing vacuolation, cam. luc. $\times 600$.

A study of various series agrees in showing only one very thin layer the ectoderm in contact with the ova except near the stomodxum. As development progresses the endoderm pushes out around the food-ova, at first with very thin flat cells, which later still become cubical and finally differentiate into the large and vacuolated definitive cells of the liver, or the columnar cells 
of the intestine. During the early part of this process, while the endoderm cells are still flat or cubical, and before their final differentiation has taken place, their nuclei exhibit unmistakable evidences of amitosis. Fig. 9 is taken from such an embryo. The food ovum, part of which is shown in the figure, is still intact; it has not yet undergone the breakdown of structure which is soon to take place. The endoderm is composed of

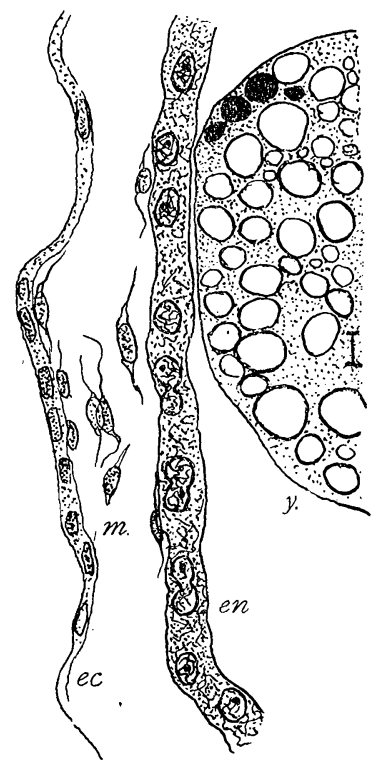

Fig. 9. - Section vertical to the ectoderm and underlying endoderm in very young embryo, scale $=$. or $\mathrm{mm}$., cam. luc, $\times 2$ rir.

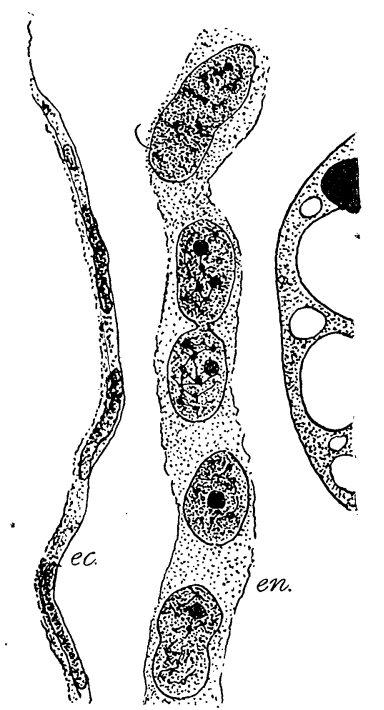

Fig, ro. - Nore highly magnified view of part of fig. $9, \times 600$.

cubical cells in which dividing nuclei are to be seen. The endoderm cells do not show any walls at this time between the cells but has the appearance in this view and in surface views of a syncytium. Walls appear at a later date and distinct cells are clearly seen in older embryos. A more highly magnified view of the cells of Fig. 9 (Fig. IO) shows nuclei at different stages of amitotic division. These views are very characteristic and found in many different places in several series of embryos of this age. They are further corroborated by flat views from places where sections are cut tangentially through the endoderm (Fig. II), in which the syncytial character of the layer is 
shown. Large nuclei of irregular shape (Fig. I 2) are also found in the endoderm of this stage; they are apparently also forms of amitotic division. Their exact relation to the more typical cases could not be determined from the material which I had. They are quite commonly to be found in embryos of a little older stage but before the endoderm has assumed its definitive form. Nuclei of both these forms predominate decidedly during the development of the embryo, but in addition to them there are occasional nuclei showing unmistakable karyokinetic figures. The latter are too infrequent to be regarded as the nuclei from which the rapidly growing endoderm is being chiefly regenerated, but there is nothing to show that they do not give rise to endoderm cells as well as the amitotic nuclei. The presence of

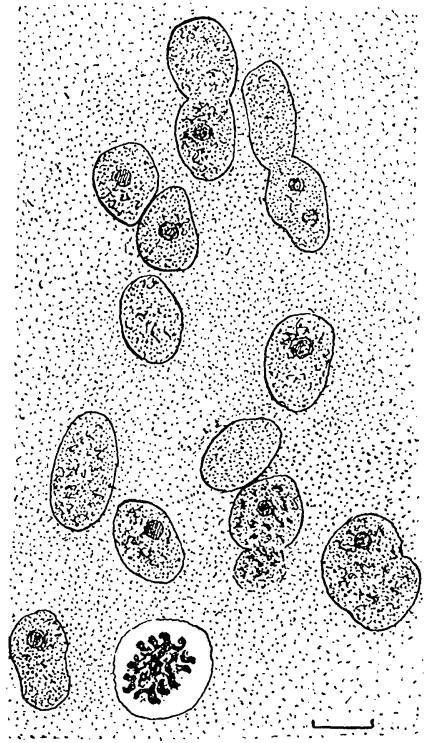

Frc. Ir. - Surface view (tangential section) of part of endoderm, showing nuclei in direct division. Scale $=$ or mm., cam. luc. $\times 600$. the mitotic figure is a guarantee of the adequacy of the technique, whatever we may think of the amitosis in these cases, at least it is not possible to dispose of them as artifacts. We recall in this connection the cases of amitosis in the intestinal cells of isopods observed by Ryder and Miss Pennington, as referred to by Conklin ('97). These were shown by him to be artifacts due to pressure in manipulation and resultant distortion. In that case the amitosis was in adult cells and the pressure was brought about by instruments and not in embryonic tissue and in a course of nature. The food-ova do not compress the endoderm, for at the time they are swallowed the layer has not as yet been formed; they grow out into the cavity after the ova have been swallowed. After a study of the available material I have not been able to resist the conviction that in Fasciolaria we find a true case of embryonic cells multiplying, contrary 
to the very general rule, by amitosis. A renewed study of this and kindred forms with reference to this point is much to be desired.

These cases of amitosis are sufficiently out of the common order to require a further study in the light of the general prin-
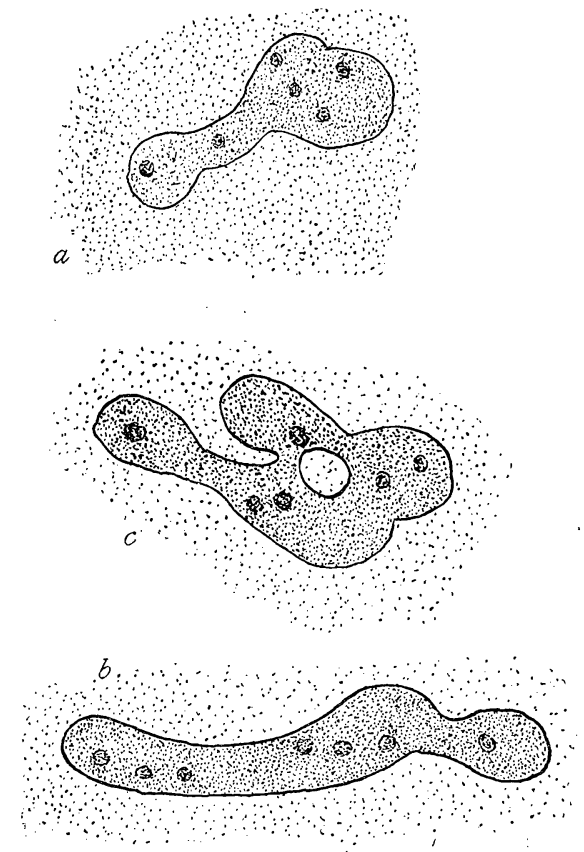

FIG. r2. - Nuclei in the endoderm, plasmodial type, cam. luc. $\times 600$. ciples relating to the amitosis question. That of the larval kidney could perhaps be attributed to senescence but hardly to metabolism, since cells are found dividing by mitosis after secretory activity has been going on to such an extent that the nucleus is distorted and crowcled into one side of the cell. The cells after they have reached a stage in which amitosis is found have apparently reached the end of their career and do not multiply further; that is, they are senescent.

It is highly remarkable that the food-ova nuclei should not divide mitotically, for the food-ova are to be interpreted as unsegmented eggs. The divisions of the nucleus in ordinary eggs both in maturation and segmentation are mitotic, and we are justified in expectingkaryokinesis of the food-ova nuclei. But instead their nuclei are queer from the first and seem to divide amitotically. This amitosis cannot be assigned to either senescence or metabolism, the cells show no signs of secretory activity, and are not senescent. The case of Spirogyra, accorcling to Pfeffer, and of the salamander, according to Meves, are somewhat analogous in that 
in both of them mitosis has been replaced by amitosis through the influence of an extraordinary circumstance, cold weather or ether. We know of no parallel to the case of the food-ova among the gasteropods. In the trematodes the yolk cells of the egg are perhaps somewhat similar; their nuclei clo not divide at all.

The nuclei of the young endoderm are also out of the ordinary course. We should expect them to divide by mitosis. While in a small percentage of cases they do divicle in that manner, in most cases the indications are strongly in favor of amitosis. Here neither senescence nor metabolism can be the cause of the amitosis. The cells have not yet arrived at their definitive form, much less become old, and secretion has not yet commenced; but, on the contrary, the cells are actively multiplying, so that they quite contradict the theory proposed by Ziegler and vom Rath.

We see, then, that while the amitosis of Fasciolaria can be attributed to senescence in one case, it cannot be attributed to either senescence or metabolism in the other two cases; and in the endoderm the amitosis is even regenerative. We have seen that senescence and metabolism cannot be regarded as causes in certain other instances of amitosis, such as those reported by Fresnel, Meves and Pfeffer. Upon the hypothesis that mitosis and amitosis are independent and non-related processes, cases of this sort are wholly unintelligible, and consequently inclicate a defect in the hypothesis, if not that it is erroneous. It is true that we do not find intermediate modes of nuclear division between mitosis and amitosis, and yet $\dot{a}$ prior $i$ we should suppose them to be related and mitosis to have been derived from amitosis. The exceptions that are being found are all of them cases in which mitosis would be looked for and amitosis is found. The frequency of mitasis in embryonic tissue does not prove that embryonic tissue cannot multiply by amitosis; it only shows that there is some reason why in most cases it does not. Since mitosis is such a delicately adjusted and complicated process, may we not suppose that a nucleus to be capable of it should be in the best possible condition, - that is, young and vigorous, - and to that end that the surrounding conditions 
should be as favorable as possible? And may we not further suppose that in the presence of conditions lowering the vigor of a nucleus, even if it were in a case where we should ordinarily expect mitosis, it would then revert to the more primitive mode of amitosis? We are not unfamiliar with the principle of physiological reversion in organs and tissues. Can we extend the principle to nuclei? If so, all the cases where amitosis occurs in a place where mitosis is expected to occur would perhaps be capable of being brought within its scope. Possibly both senescence and secretion as causes of amitosis could be interpreted in the same way. Thus senescence as a cause of amitosis, as it undoubtedly is, would be in reality due to the lowered vitality of the cell consequent on age. Metabolism perhaps could be supposed to cause it, where there is not at the same time, as in fat cells, milk cells and others, senescence, through the presence of the secretion which may exercise an unfavorable influence on the nucleus chemically. Pathologic tissues would also find an easy explanation on this basis to account for the common occurrence of amitosis in them. Summer by inducing optimal wellbeing of the cell would put it in condition for mitosis; winter by lowering its vitality would render it unable to divide by mitosis but not by amitosis. Pfeffer's observation on the effect of ether would also fall in line, the cell tending to divide by mitosis but being prevented by the interference with its powers consequent on the influence of the ether. In Fasciola the larval kidney cells while young still divide by mitosis and are consequently vigorous, notwithstanding the presence of consiclerable metabolic material, but as they become old they lose this power and divide by amitosis. The food-ova with their tendency to mitosis are placed in conditions so unfavorable to their well-being that cell division does not take place at all and nuclear division is only by amitosis. The deeply staining granular particles in some of them may be imperfectly formed chromosomes, as if mitosis had been attempted but without success. A careful cytological study of these food-ova would be very likely to repay study, as it might throw light on the relation between the two modes of nuclear division. The endoderm cells are developing in the amitotic manner and this is the chief 
mode by which the embryonic gut enclosure is taking place, if not the only mode. In their case neither senescence nor metabolism can be urged as the cause of the amitosis. Under ordinary circumstances we should find the endoderm increasing by mitosis, but here the mode of growth is very extraordinary, and the case only finds explanation on the principle I have been indicating. I do not know just what particular cause should be assigned in the case of the endoderm, which is to be considered as interfering with the mitosis; perhaps it is the pressure conditions existing in the enteron owing to the presence of such a large amount of inert and foreign matter; perhaps it is the absence of the most favorable food for the endoderm, since the food-ova have not yet begun to be consumed.

Note-- Since revising the last proof of this article, the writer has read with interest a passage in Dr. Davis' article (Am. Nat. 38, p. 434) containing much the same idea vid._- "It is possible that direct division in the higher plants is in a sense a reversion to early ancestral conditions, a reversion that comes on only' wohen for some reason the nomal actiontics of the germ cell are in abeyance or have ceased."

\section{BIBLIOGRAPHY.}

Brooks, W. K. ANd Heririck, F. H.

'92. The Embryology and Metamorphosis of the Macroura. Mem. Acad. Nat. Sci., rol. 5 .

Conklin, E. G.

'97. The Relation of the Nuclei and Cytoplasm in the Intestinal Cells of Land Isopods. Am. Nat., vol. $3 \mathrm{I}$.

FRENZEL, J.

'85. Ueber den Darmkanal der Crustaceen nebst Bemerkungen zur Epithelregeneration. Arch. f. mik. Anat., vol. 25, p. I37.

Johnson, H. P.

'92. Amitosis in the Embryonal Envelopes of the Scorpion. Bull. Mus. Comp. Zool., vol. 22.

MACMURRich, J. P.

'87. A Contribution to the Embryology of the Prosobranch Gasteropods. Biol. Stud. Johns Hopk. Univ., vol. 3 . 
Meves, F.

'91. Ueber amitotische Kerntheilung in den Spermatgonien des Salamanders. Anat. Anzeig., 6.

OsBoRn, H. L.

'85. Development of the Gill in Fasciolaria. Biol. Stud. Johns Hopk. Univ., vol. 3 .

\section{PFEFFER,}

'99. Ueber die Erzeugung und Physiologische Bedeutung. der Amitose. Ber. koenigl. sachs. Ges. Wiss. Leipsig.

Preusse.

'95. Ueber die amitotische Kerntheilung in den Ovarien der Hemipteren. Zeit. f. w. Zool., vol. 59.

VERSON, E.

'91. Zur Beurtheilung der amitotischen Kerntheilung. Biol. Cent., vol. 9 .

VOM RATH, O.

'91. Ueber die Bedeutung amitotische Kerntheilung im Hoden. Zool. Anz., vol. I 4 .

'94. Beit. z. Kent. der Spermatogenesis von Salamandra maculosa. ii, Theil, Die Bedeutung amitosis, etc. Zeit. f. w. Zool., vol. 57.

WALDEYER, W.

'90. Karyokinesis and its Relation to Fertilization. Q. Jnl. Mic. Sci., vol. 30 .

WheEler, W. M.

'89. The Embryology of Blatta and Doryphora. Am. Jnl. Morphol. vol. 3 .

Wilson, E. B.

:00. The Cell in Development and Inheritance. Columbia Biological Series.

Ziegler, H. E.

'91. Die biologische Bedeutung der amitotische Kerntheilung im Tierreich. Biol. Cent. vol. I I.

Brological LabORatory OF HaMidne University,

Saint Paul, Minn.

April 25, 1904 .

This content downloaded from 191.191.244.048 on February 18, 2018 20:17:56 PM All use subject to University of Chicago Press Terms and Conditions (http://www.journals.uchicago.edu/t-an 